\title{
PRELIMINARY ASSESSMENT OF TRANSPORT VARIABILITY OF SUSPENDED RIVER LOAD IN THE CHAŁUPKI CROSS-SECTION ON THE UPPER ODER
}

\author{
Robert Głowski, Robert Kasperek \\ Institute of Environmental Engineering, Wrocław University of Environmental and Life Sciences, pl. Grunwaldzki 24, \\ 50-363 Wrocław
}

\begin{abstract}
Aim of the paper

The aim of the study was to analyse the reasons for the occurrence of intensive suspended load transport in the area of meander 1 . The river load transport caused significant morphological changes in the Upper Oder River bed system.
\end{abstract}

\begin{abstract}
Material and methods
For 16 years, the authors observed and studied the course of significant and quite intensive changes in the morphological system of the Upper Oder bed at the meandering section of the river in the vicinity of the Chałupki village. The course of these changes resulted in the creation of a new cut-off oxbow lake and shortening of the river course by about $1200 \mathrm{~m}$. Trying to explain the course of these changes and the intensity of this process, the authors analysed hydrological data on the volume of suspended river load from 31 years (from 1969 to 2002).
\end{abstract}

\begin{abstract}
Results and conclusions
The analysis of changes in the intensity of suspended load transport in the flow function in the cross-section of Chałupki showed that the transport takes place virtually in the full range of flows specified in the hydrological characteristics for the analysed section and is mass. Maximum transport values can reach even $4000 \mathrm{~g} / \mathrm{m}^{3}$. With an increase in average flows to about $250 \mathrm{~m}^{3} \cdot \mathrm{s}^{-1}$, the intensity of suspended load increases and at higher flows $\left(\mathrm{Q}>250 \mathrm{~m}^{3} \cdot \mathrm{s}^{-1}\right)$ the flow course is disturbed. At higher flow rates, smaller river load transport values occur. This would indicate (Morris and Fun, 1998) that the amount of river load eroded from the bottom of the river on a given section is possibly limited and associated with the presence of thick river load fractions (river bottom armouring or a rocky ground) below eroded sediments. This would confirmed by the earlier research of the authors on the mechanism of the course of morphological changes in the analysed section of the river (Głowski and Parzonka, 2008; Parzonka et al., 2006). Further research is needed to find out the exact causes of rapid morphological changes in the Oder River bed in the research area and to identify the mechanism of river load transport in this area.
\end{abstract}

Keywords: river load transport, suspended load, river morphology 


\section{INTRODUCTION}

The issues of transport and sedimentation of solid particles forming liquid - solid mixtures are important for many fields of industry and economy (Bandrowski et al., 2001; Głowski and Kasperek, 2017). This article concerns the process of transporting suspended river load and morphological changes of river beds and river valleys caused by this process. The volume of transport and the sedimentation of solid particles is important, among others, for water quality (Kasperek and Wiatkowski, 2008; Kostecki 2003; Wiatkowski and Wiatkowska, 2019), changes in the capacity of water reservoirs (Lajczak, 1995; Głowski and Kasperek, 2017), functioning of water intakes for agricultural or water supply systems, shipping, etc. It also plays an important role in the course of morphological changes of river valleys and river beds (Łajczak, 1999; Czajka, 2007; Czajka and Ciszewski, 2009). River load transport and sedimentation are the cause of spatial morphological changes in river beds and river valleys. As a result, e.g. flood plains are subject to overlaying of sediment (Łajczak, 1999; Czajka and Ciszewski, 2009), or in extreme cases, changes in the river course, flow capacity of river bed or valley occur, especially when high flows happem (Głowski and Parzonka, 2008). Morphological changes in the arrangement of river beds also affect water relations in adjacent areas and the natural environment (Pływaczyk, 1988). An example of environmental impact is the formation of oxbow lakes and their subsequent natural transformation into a hydraulically inactive river bed areas with changing natural values, most often as a result of overgrowing and further periodic overlaying with river load. The authors observed the course of such changes on the Polish-Czech border section of the mountain Oder near the village of Chałupki-Bohumin for 16 years. The changes began with the July flood of 1997. In the article, the authors made an attempt to characterise the variability of the volume of transported river load on the investigated section of the Oder River and the assessment of the volume of transport intensity of transported river load which caused such a rapid morphological change in the Oder River bed in 1997.

\section{RESEARCH SITE}

On the section of the Mountain Oder from Chałupki to the estuary of the Oder River there are 7 unique meanders on a European scale (see: Fig. 1). On this section, the Oder River is unregulated, however, above and below the meandering section, it has been regulated. The meandering section of the river is subject to anthropopressure related to the existence of the Ostrava-Karviná Coal Basin (OKCB). The large-scale discharge of sewage from OKCB caused, among others, increased transport of suspended matter, which was particularly observable in the 1980s (Ciszewski and Czajka, 2009). Since 2002 , the area of meanders has been included in the Natura 2000 programme. The event history dates back to 1997, when during a catastrophic flood with a maximum flow of $Q_{\max }=2160 \mathrm{~m}^{3} \cdot \mathrm{s}^{-1}$, the inlet to the first meander was cut off as a result of mass transport of river load. Almost simultaneously with the closing of the inlet to this meander, the river created a new river bed and locally shortened the Oder by about $1200 \mathrm{~m}$, due to sedimentation of the load. A detailed description of the emergence of morphological changes in the area of inlet to meander 1 has been described in earlier author's publications, e.g. (Głowski and Parzonka, 2008). It should be noted that the observed morphological change was of a rapid nature and arose as part of one flood event.

\section{CHARACTERISTICS OF HYDROLOGICAL CONDITIONS ON THE ANALYSED SECTION OF THE ODER RIVER}

In Chałupki, there are two water gauge stations: Czech and Polish. The Polish water gauge station is controlled by the Polish Institute of Meteorology and Water Management in Katowice. The Czech water gauge remains under the control of the Czech hydrological service of Povodi Odra in Ostrava. In current conditions, the distribution of states and flows on the analysed section of the Oder is as follows:

- zone of low levels and flows, corresponding to $\mathrm{H}<160 \mathrm{~cm}$ fillings and $\mathrm{Q}<12.4 \mathrm{~m}^{3} \cdot \mathrm{s}^{-1}$ flows,

- zone of medium levels and flows, corresponding to $160<\mathrm{H}<260 \mathrm{~cm}$ fillings and $12.4<\mathrm{Q}<72 \mathrm{~m}^{3} \cdot \mathrm{s}^{-1}$ flows,

- zone of high levels and flows, corresponding to $\mathrm{H}>260 \mathrm{~cm}$ fillings and $\mathrm{Q}>72 \mathrm{~m}^{3} \cdot \mathrm{s}^{-1}$ flows. 


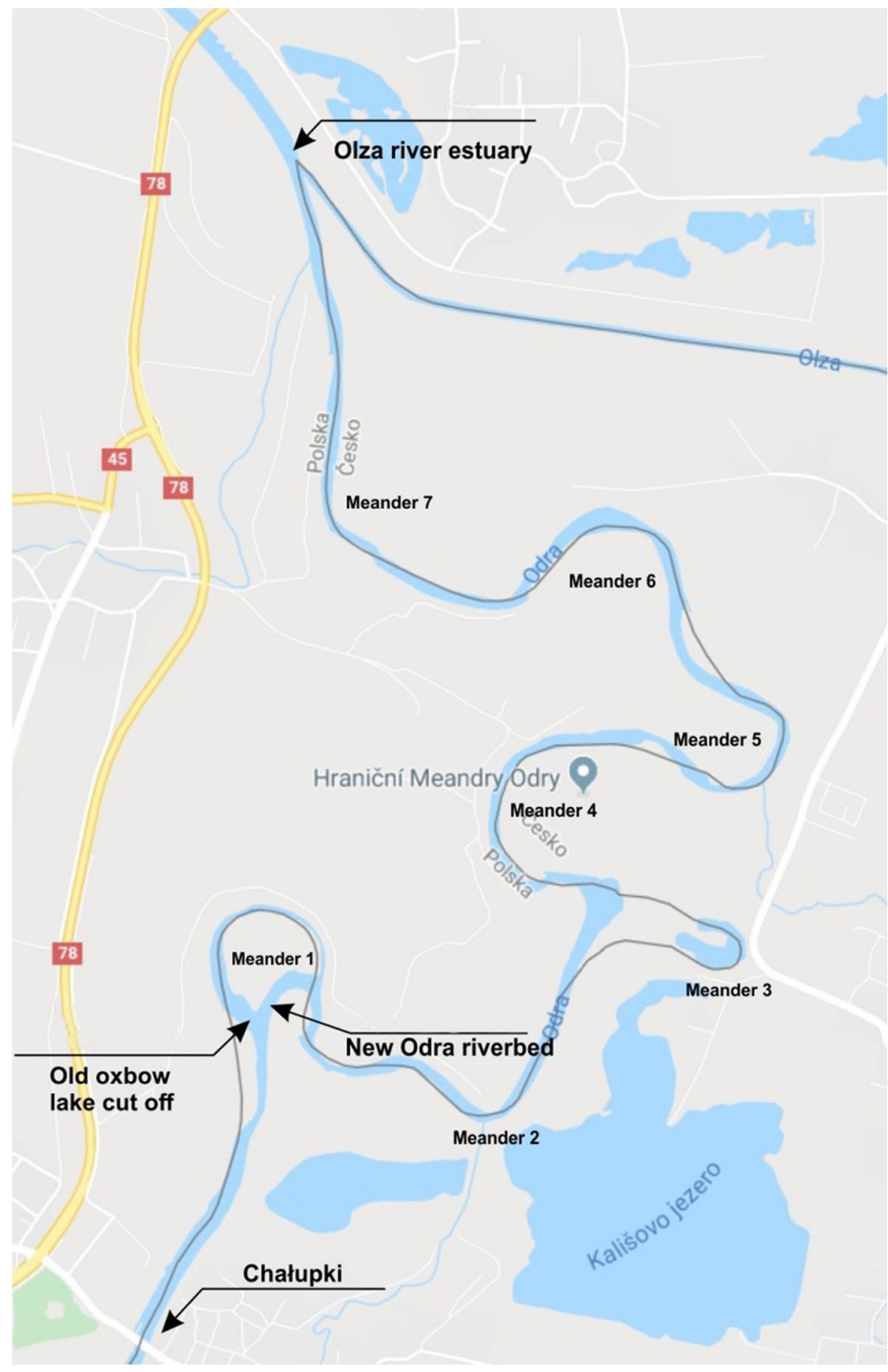

Fig. 1. The Upper Oder River section between the Chałupki Village and the Olza River estuary. Map from Google Maps 


\section{DATA ANALYSIS}

In the analysis, the following data were used: measurement data from the water gauge cross-section in Chałupki from 1969 to 2002, published in the Hydrological Annuals (1969-1983), and measurement data obtained from the Voivodeship Environmental Protection Inspectorate in Katowice (1984-2002). The measured data on the river load transport intensity $\mathrm{U}$ expressed in $\left(\mathrm{mg} \cdot \mathrm{dm}^{-3}\right)$ were converted to $\left(\mathrm{g} \cdot \mathrm{m}^{-3}\right)$.

The attempt to characterise the variability of the volume of river load transported on the investigated section of the Oder River and to determine the relationship between the volume of transport intensity and the flow rate is connected to the search for a cause of the sudden change in the morphological system of the Oder River bed in the region of meander 1 observed by the authors. In the analysis, it was assumed that the transport inten- sity of the suspended load is a function of flow. To identify the river load displacement regime in the analysed cross-section of the river, hydrographs of flows and corresponding values of transported load were done. Figure 2 shows an exemplary hydrograph of flow rate and suspended load transport. The created hydrographs may reflect various relationships of suspended load transport as a function of flow (Morris and Fun, 1998). The obtained hydrographs for the Oder River in the Chałupki cross-section (data for the analysed period) show that the maximum values of suspended load transport are slightly ahead of the moment of occurence of the maximum flow. Such a hydrograph pattern is common (Morris and Fun, 1998) and can occur in 3 cases:

a) when there is easily erodible material in the catchment, or sediments accumulated by an earlier flood event have been deposited in the river bed and the current flood causes their resuspension,

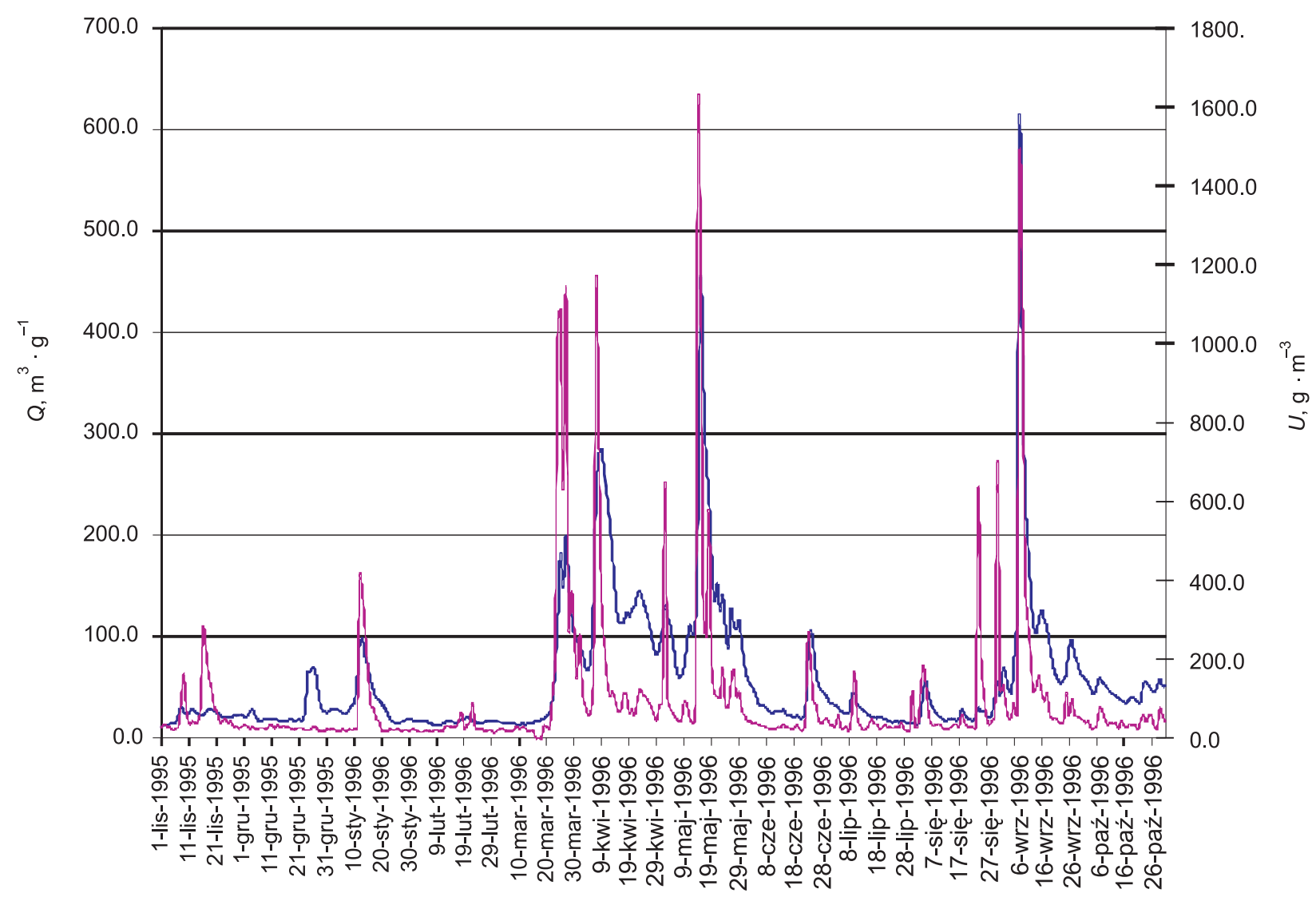

Fig. 2. An example of relations between river flow rate and suspended load transport rate 
b) possibility of river load erosion from a river bottom is limited and connected to thick river load fractions lying below sediments subject to erosion (bottom imbrication phenomenon or rocky ground),

c) variability of rainfall intensity and erosion in the catchment can cause high production of suspended load within the catchment outlet during the rising of the flood wave.

In addition, such a course of hydrographs may occur when flushing reservoires from residual sediments during flow increases and water accumulation in reservoires during the wave recession phase (water contains less river load). To assess the variability of suspended load transport volume over a period of 31 years, the following events were taken into account, when necessary: significant suspended load transport heights. The flow range was divided into ranges according to the following scheme: $0<$ $\mathrm{Q} \leq 51 \mathrm{~m}^{3} \cdot \mathrm{s}^{-1}, 51<\mathrm{Q} \leq 101 \mathrm{~m}^{3} \cdot \mathrm{s}^{-1}$ etc. The flows included in individual intervals were assigned corresponding measured values of suspended load transport intensity.
All the created hydrographs, such as the example shown in Figure 2, showed that in most of the flood events a characteristic feature of the analysed cross-section in Chałupki there is a slight precedence of the occurence of the maximum suspended load transport volume in relation to the occurence of maximum flow (the peak of the sedimentogram precedes the peak of the flood wave). The analysis contained single hydrograms where the peak of the flood wave coincided with the peak of the sedimentogram wave. The occurrence of this type of relationship was described by Morris and Fun (Morris and Fun, 1998). In the analysis, it was assumed that as the flow rate increases, the value of suspended load transport rate also increases. The developed relationships, suspended load transport volumes and flows in individual flow ranges are shown in Figure 3. Figure 3 presents the obtained image of the variability of measured suspended load transport as a function of flows from a given range.

At flows above $\mathrm{Q}=400 \mathrm{~m}^{3} \cdot \mathrm{s}^{-1}$, there were single suspended load transport events were found in the analysed 31-year period, the list is presented in Table 1.

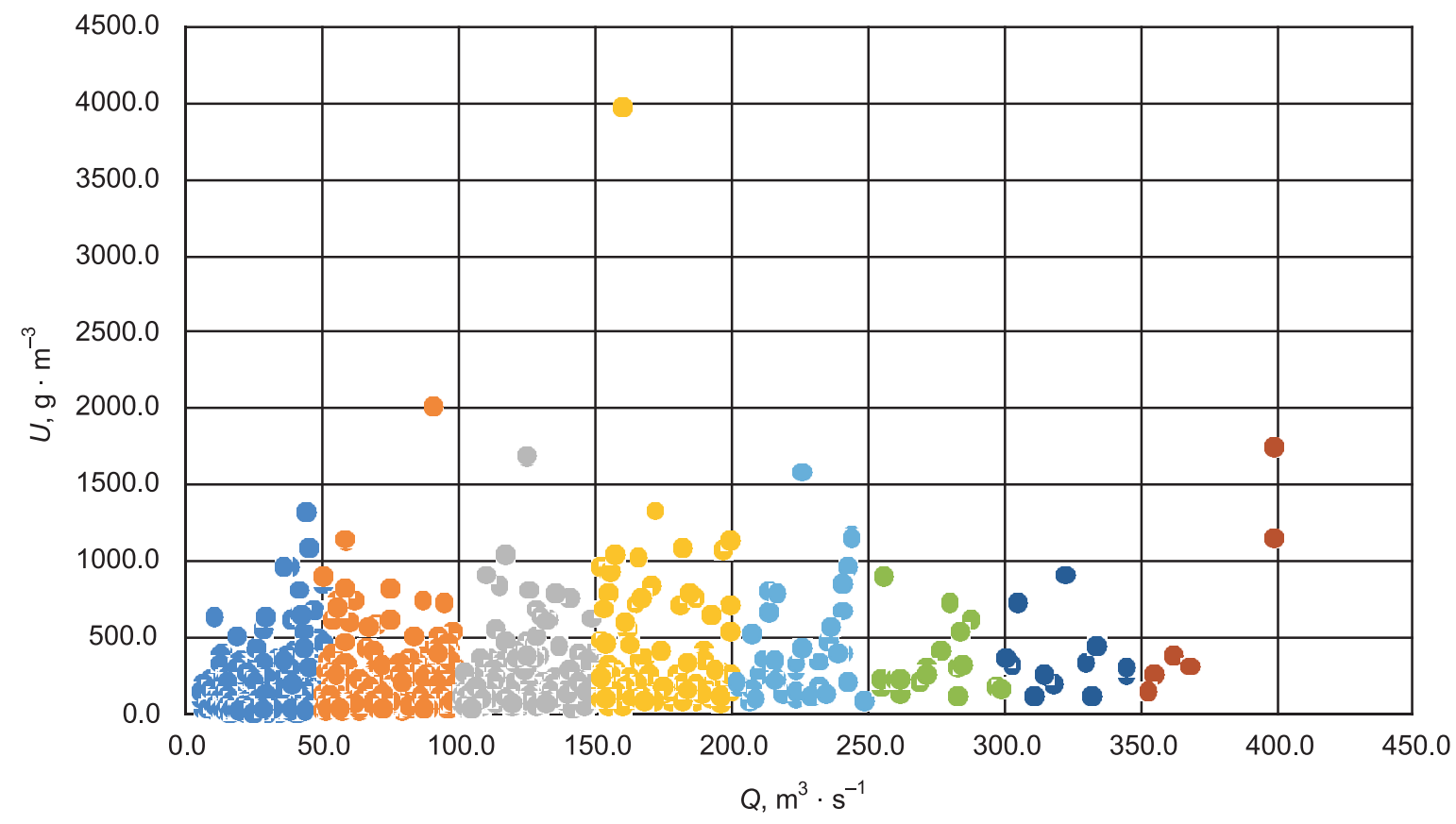

Fig. 3. Variability of suspended load transport in individually analysed flow ranges 
Głowski, R., Kasperek, R. (2019). Preliminary assessment of transport variability of suspended river load in the Chałupki cross-section on the upper Oder. Acta Sci. Pol., Formatio Circumiectus, 18 (4), 151-159. DOI: http://dx.doi.org/10.15576/ASP.FC/2019.18.4.151

Table 1. Single occurrences of the suspended load transport at flow rates higher than $400 \mathrm{~m}^{3} \cdot \mathrm{s}^{-1}$

\begin{tabular}{lccccc}
\hline Flow range $\mathrm{Q}\left(\mathrm{m}^{3} \cdot \mathrm{s}^{-1}\right)$ & Number of events & $\mathrm{Q}_{\text {avg }}\left(\mathrm{m}^{3} \cdot \mathrm{s}^{-1}\right)$ & $\mathrm{U}_{\text {avg }}\left(\mathrm{g} \cdot \mathrm{m}^{-3}\right)$ & $\mathrm{Q}_{\max }\left(\mathrm{m}^{3} \cdot \mathrm{s}^{-1}\right)$ & $\mathrm{U}_{\max }\left(\mathrm{g} \cdot \mathrm{m}^{-3}\right)$ \\
\hline $401<\mathrm{Q} \leq 450$ & 2 & 428 & 294 & 424 & 448 \\
\hline $451<\mathrm{Q} \leq 500$ & 2 & 463 & 901 & 469 & 1360 \\
\hline $501<\mathrm{Q} \leq 550$ & 1 & 507 & 198 & 507 & 198 \\
\hline $551<\mathrm{Q} \leq 600$ & 1 & 590 & 182 & 590 & 1455 \\
\hline $601<\mathrm{Q} \leq 650$ & 1 & 608 & 1455 & 608 & 240 \\
\hline $651<\mathrm{Q} \leq 700$ & \multicolumn{5}{c}{5} \\
\hline $701<\mathrm{Q} \leq 750$ & 1 & no data & 711 \\
\hline $751<\mathrm{Q} \leq 800$ & 2 & 240 & 760 \\
\hline $\mathrm{Q}>801$ & 757 & 403 & no data \\
\hline
\end{tabular}

\section{DISCUSSION OF RESULTS}

The developed dependence of suspended load transport intensity as a function of flows (see: Fig. 3) shows a significant differentiation in the values of suspended load intensity for the Chałupki cross-section. According to the assumption, along with the increase in flow rate, the values of suspended load transport should increase and from the developed dependences it can be concluded that low rate flows sometimes generate higher suspended load transport volumes than high rate flows. The scatter of values (points) on the developed charts is significant, the authors were unable to find a satisfactory relation between the flow rate and the generated value of suspended load transport volume in individual flow ranges. It should be mentioned that during the data analysis, the occurrence of single events (one-day episodes) was found when, with a slight increase in flow, a high value of the measured volume of suspended load occurs. For example, an event from the 1-3 March 1996 period, when on the 1 May the flow was $108 \mathrm{~m}^{3} \cdot \mathrm{s}^{-1}$ and the measured transport volume $U=88 \mathrm{~g} \cdot \mathrm{m}^{-3}$, and already on 2 May 1996 the flow increased to $Q=130 \mathrm{~m}^{3} \cdot \mathrm{s}^{-1}\left(22 \mathrm{~m}^{3} \cdot \mathrm{s}^{-1}\right.$ difference $)$ and the measured suspended load transport volume increased to $U=648 \mathrm{~g} \cdot \mathrm{m}^{-3}$, and then, on 3 May 1996 , the flow rate is $Q=119 \mathrm{~m}^{3} \cdot \mathrm{s}^{-1}$ and the suspended load volume $U=100 \mathrm{~g} \cdot \mathrm{m}^{-3}$. The source of these episodic events can be sewage discharges (Ciszewski and Czajka 2009) or discharges from reservoires, e.g. from OKCB area (Ciszewski and Czajka 2009; Morris and
Fun, 1998; Jarocki, 1968). Considering the lack of correlation between the flows and the values of the measured suspended load transport volumes, the authors determined average flow rates and average suspended load transport volumes for the analysed 1969-2002 period. Averaged values were established for events in which significant suspended load transport values appeared along with the increase in flows. The results are shown in Table 2. It can be observed that when considering the average values of flows and suspended load transport rates, in the flow range $0<\mathrm{Q} \leq 250 \mathrm{~m}^{3} \cdot \mathrm{s}^{-1}$ there is an increase in the volume of suspended load transport. At higher flows $\mathrm{Q}>250 \mathrm{~m}^{3} \cdot \mathrm{s}^{-1}$ the course of the phenomenon is disturbed, at higher flow values smaller suspended load transport values appear (see: Table 2). The probable reason for this flow-intensity relationship is the possibility described by Morris and Fun (1998) that the amount of river load eroded from the river bottom on a given section is limited and connected to the presence of thick river load fractions below eroded sediments (bottom armouring or rocky ground). This would be confirmed by the earlier research of the authors on the functioning of the course of morphological changes on the analysed section of the river (Głowski and Parzonka 2008; Parzonka et al., 2006). At that time, the authors concluded on the basis of field studies that the foundation of the islands closing the inlet of meander 1 is coarse-grained load.

The authors also conducted an analysis of the increase of suspended load transport volume as a function of flow increase, see Figure 4. The obtained de- 
pendence confirmed a significant variability in the volume increases of the suspended load transports as the flow increased.

The authors see the need for further research to identify the causes of such significant changes in the value of suspended load transport volume as a function of flows and to take them into account in further analysis. In the preliminary analysis presented in this article, the authors attempted to find relationships between the value of suspended load transport volume and the flow for "raw" measurement data. It is necessary to extend the scope of the analysed data to 2019; analyse them further taking into account the recognition of the system of water discharges from water reservoirs located above the analysed cross-section on both the Czech and the Polish side; find potential sewage discharge locations and estimate the amount of suspended load introduced along with these discharges to the waters of the Oder River. The authors plan to obtain data from the Polish Institute of Meteorology and Water Management and to conduct such research in the future.

Table 2. Summary of average and maximum values of flows and suspended load transport

\begin{tabular}{ccccc}
\hline $\begin{array}{c}\text { Flow range } \boldsymbol{Q} \\
\left(\mathrm{m}^{3} \cdot \mathrm{s}^{-1}\right)\end{array}$ & $\begin{array}{c}\boldsymbol{Q}_{\text {avg }} \\
\left(\mathrm{m}^{3} \cdot \mathrm{s}^{-1}\right)\end{array}$ & $\begin{array}{c}\boldsymbol{U}_{\text {avg }} \\
\left(\mathrm{g} \cdot \mathrm{m}^{-3}\right)\end{array}$ & $\begin{array}{c}\boldsymbol{Q}_{\text {max }} \\
\left(\mathrm{m}^{3} \cdot \mathrm{s}^{-1}\right)\end{array}$ & $\begin{array}{c}\boldsymbol{U}_{\text {max }} \\
\left(\mathrm{g} \cdot \mathrm{m}^{-3}\right)\end{array}$ \\
\hline $0-50$ & 28.9 & 124.6 & 44.5 & 1326.0 \\
\hline $51-100$ & 72.4 & 147.1 & 91.0 & 2012.0 \\
\hline $101-150$ & 123.2 & 214.3 & 125.0 & 1695.0 \\
\hline $151-200$ & 170.2 & 343.3 & 160.0 & 3970.0 \\
\hline $201-250$ & 225.2 & 441.0 & 226.0 & 1585.0 \\
\hline $251-300$ & 274.4 & 340.6 & 256.0 & 909.0 \\
\hline $301-350$ & 321.8 & 367.2 & 323.0 & 914.0 \\
\hline $351-400$ & 372.7 & 672.5 & 399.0 & 1749.0 \\
\hline $401-450$ & 428.0 & 294.0 & 424.0 & 448.0 \\
\hline $451-500$ & 463.0 & 901.4 & 469.0 & 1360.0 \\
\hline $501-550$ & 507.0 & 198.0 & 507.0 & 198.0 \\
\hline $551-600$ & 590.0 & 182.0 & 590.0 & 182.0 \\
\hline $601-650$ & 608.0 & 1455.0 & 608.0 & 1455.0 \\
\hline $651-700$ & 711.0 & 240.0 & 711.0 & 240.0 \\
\hline $701-751$ & 757.0 & 403.0 & 760.0 & 526.0 \\
\hline
\end{tabular}

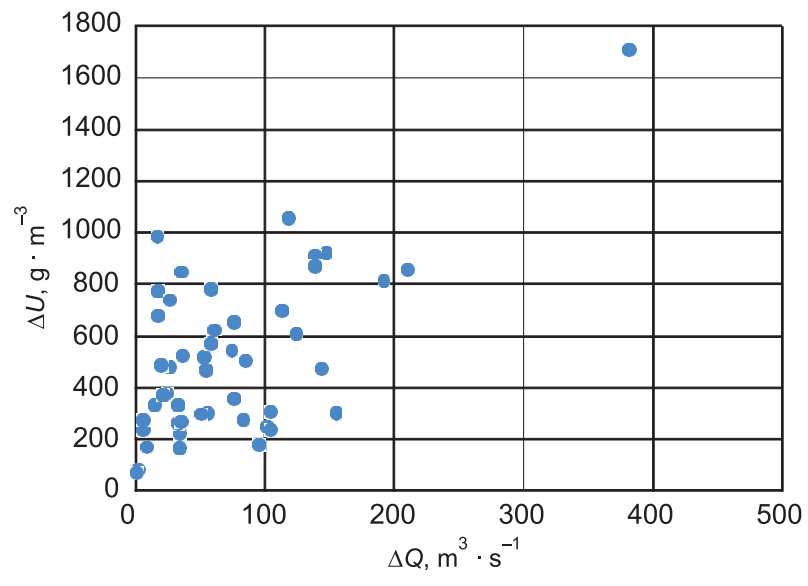

Fig. 4. Increase of suspended load transport intensity as a function of flow increase

\section{CONCLUSIONS}

The analysis of changes in the intensity of suspended load transport carried in the function of flow in the Chałupki cross-section showed that the transport takes place virtually in the full range of flows specified in the hydrological characteristics for the analysed section. It is characterised by considerable variability, maximum values can reach even $4000 \mathrm{~g} \cdot \mathrm{m}^{-3}$. With average flows increasing to about $250 \mathrm{~m}^{3} \cdot \mathrm{s}^{-1}$, the intensity of suspended load transport increases. At higher flows $\mathrm{Q}>250 \mathrm{~m}^{3} \cdot \mathrm{s}^{-1}$, the course of the phenomenon is disturbed, at higher flow rates, smaller suspended load transport values occur. This would indicate (Morris and Fun, 1998) that the amount of river load eroded from the bottom of the river on a given section is possibly limited and associated with the presence of thick river load fractions (river bottom imbrication phenomenon or a rocky ground) below eroded sediments. This would be confirmed by the earlier research of the authors on the functioning of the course of morphological changes on the analysed section of the river (Głowski and Parzonka 2008; Parzonka et al., 2006).

In the cross-section of Chałupki there are episodic, single events of a slight increase in flows during which the intensity of suspended load transport increases significantly. The causes of all events affecting the course of the phenomenon should be explained in further research to include their impact in the analysis. 
In the preliminary analysis presented in this article, the authors attempted to find relationships between the value of suspended load transport volume and the flow for "raw" measurement data. Due to the large variability of suspended load transport in the flow function, the authors were unable to clearly determine the functional relationship for the analysed issue. It is necessary to extend the scope of the analysed data to 2019; analyse them further taking into account the recognition of the system of water discharges from water reservoirs located above the analysed cross-section on both the Czech and the Polish side; find potential sewage discharge locations and estimate the amount of suspended load introduced along with these discharges to the waters of the Oder River. The authors plan to obtain data from the Polish Institute of Meteorology and Water Management and to conduct such research in the future.

\section{REFERENCES}

Bandrowski, J., Merta, H., Zioło, J. (2001). Sedymentacja zawiesin - zasady i projektowanie, Gliwice: Wyd. Politechniki Śląskiej.

Ciszewski, D., Czajka, A. (2009). Akumulacja osadów na równinach zalewowych rzek silnie zmienionych antropogenicznie: Górna Wisła i Odra, Przegląd Geologiczny, $57,7$.

Czajka, A. (2007). Środowisko sedymentacji osadów przykorytowych rzek uregulowanych na przykładzie Górnej Odry i Górnej Wisły. Katowice: Wydawnictwo Uniwersytetu Śląskiego.

Głowski, R., Parzonka, W. (2008). Erosion regime of semi-cohesive Island muds from meander 1 in frontier Upper Odra, Saint Petersburg State Mining Institute (Technical University).

Głowski, R., Kasperek, R. (2017). The grain size distri- bution of settled sediment within storage reservoir Otmuchów, Annals of Warsaw University of Life Sciences - SGGW Land Reclamation, 49(1).

Jarocki, W. (1957). Ruch rumowiska w ciekach. Gdynia: Wydawnictwo Morskie.

Kasperek, R., Wiatkowski, M. (2008). Badania osadów dennych ze zbiornika Mściwojów, Przegląd Naukowy Inżynieria i Kształtowanie Środowiska, XVII, 2 (40).

Kostecki, M. (2003). Alokacja i przemiany wybranych zanieczyszczeń w zbiornikach zaporowych hydrowęzła rzeki Kłodnicy i Kanale Gliwickim. Zabrze: Instytut Inżynierii Środowiska PAN.

Łajczak, A. (1995). Studium nad zamulaniem wybranych zbiorników zaporowych w dorzeczu Wisły. Warszawa: Oficyna Wydawnicza Politechniki Warszawskiej.

Łajczak, A. (1999). Współczesny transport i sedymentacja materiału unoszonego w Wiśle i głównych dopływach. Warszawa: Oficyna Wydawnicza Politechniki Warszawskiej.

Morris, L. G., Fan J. (1998). Reservoir Sedimentation Handbook, McGraw-Hill.

Parzonka, W., Głowski, R., Kasperek, R. (2006). Ocena przepustowości doliny Górnej Odry między Chałupkami a ujściem Olzy, Infrastruktura i Ekologia Terenów Wiejskich, PAN Kraków, 4/2.

Pływaczyk, L. (1988). Oddziaływanie Odry na stosunki wodnomelioracyjne doliny w rejonie Brzeg Dolny Malczyce, Rozprawa. Wrocław: Wyd. Akademii Rolniczej we Wrocławiu.

Wiatkowski, M., Wiatkowska, B. (2019). Changes in the flow and quality of water in the dam reservoir of the Mała Panew catchment (South Poland) characterized by multidimensional data analysis. Archives of Environmental Protection; 45(1), 26-41. DOI:10.24425/ aep.2019.126339.

Yalin, S. M., Ferreira da Silva, M. A. (2001). Fluvial processes, Monographs, International Association of Hydraulic Engineering and Research.

\section{WSTĘPNA OCENA ZMIENNOŚCI TRANSPORTU RUMOWISKA UNOSZONEGO W PRZEKROJU CHAŁUPKI NA GÓRNEJ ODRZE}

\section{ABSTRAKT}

\section{Cel pracy}

Celem pracy była analiza przyczyn wystapienia intensywnego transportu rumowiska unoszonego w rejonie meandra 1. Transport rumowiska spowodował powstanie istotnych zmian morfologicznych w układzie koryta Górnej Odry. 


\section{Materiały i metody}

Autorzy przez 16 lat obserwowali i badali przebieg istotnych i postępujących dość intensywnie zmian układu morfologicznego koryta Górnej Odry na meandrującym odcinku rzeki w rejonie miejscowości Chałupki. Przebieg tych zmian spowodował powstanie nowego odciętego starorzecza i skrócenie biegu rzeki o około 1200 m. Próbując wyjaśnić przebieg tych zmian i intensywność tego procesu, autorzy przeanalizowali dane hydrologiczne dotyczące wielkości transportu rumowiska unoszonego z 31 lat (okres od roku 1969 do 2002).

\section{Wyniki i wnioski}

Przeprowadzona analiza zmian intensywności transportu rumowiska unoszonego w funkcji przepływu w przekroju Chałupki wykazała, że transport odbywa się praktycznie w pełnym zakresie przepływów określonych w charakterystyce hydrologicznej dla analizowanego odcinka i ma charakter masowy. Maksymalne wartości transportu mogą osiagać nawet $4000 \mathrm{~g} \cdot \mathrm{m}^{-3}$. Przy wzroście przepływów średnich do około $250 \mathrm{~m}^{3} \cdot \mathrm{s}^{-1}$, intensywność transportu rumowiska unoszonego wzrasta a przy przepływach większych $\left(\mathrm{Q}>250 \mathrm{~m}^{3} \cdot \mathrm{s}^{-1}\right)$ przebieg zjawiska ulega zakłóceniu. Przy wyższych wartościach przepływów pojawiają się mniejsze wartości transportu rumowiska. Wskazywałoby to (Morris i Fun, 1998) na możliwość, że erodowana z dna rzeki ilość rumowiska na danym odcinku jest ograniczona i związana z zaleganiem poniżej erodowanych osadów, grubych frakcji rumowiska (zjawisko obrukowania dna lub podłoże skaliste). Potwierdzały by to wcześniejsze badania autorów dotyczące mechanizmu przebiegu zmian morfologicznych na analizowanym odcinku rzeki (Głowski i Parzonka 2008, Parzonka i in., 2006). Dla poznania dokładnych przyczyn powstania gwałtownych zmian morfologicznych koryta Odry w rejonie badawczym i rozpoznania mechanizmu transportu rumowiska w tym rejonie konieczne są dalsze badania.

Słowa kluczowe: transport rumowiska, rumowisko unoszone, morfologia rzek 